\title{
Fluid Evolution of the Čukaru Peki Cu-Au Porphyry System (East Serbia) inferred from a fluid inclusion study
}

\author{
Velojić Miloš, Jelenković Rade and Cvetković Vladica \\ University of Belgrade, Faculty of Mining and Geology, Đušina 7, 11000 Belgrade, Serbia
}

doi: $10.4154 / g c .2020 .14$

\section{Article history:}

Manuscript received April 15, 2020

Revised manuscript accepted September 23, 2020 Available online October 23, 2020
Keywords: Bor metallogenic zone, Timok magmatic complex, fluid inclusions, porphyry Cu deposit, massive sulphides, brines, fluid boiling

\begin{abstract}
Čukaru Peki is a recently discovered copper-gold deposit in the Bor metallogenic zone in east Serbia. Three types of mineralization can be distinguished in this ore deposit: porphyry, highsulphidation, and transitional epithermal type. This research was focused on fluid inclusion analysis of genetically different veins from the porphyry and the transitional zones of Čukaru Peki with an aim of better understanding the fluid evolution and mineralization processes in this system. Seven types of veins were identified in the porphyry zone of Cukaru Peki and four of these veins contained transparent minerals which were suitable for fluid inclusion analysis. Eight types of inclusion assemblages were distinguished in these veins: type 1 - primary inclusions with homogenization temperatures above $550^{\circ} \mathrm{C}$ and high salinity, type $2 \mathrm{a}$ - scattered polyphase inclusions with two salt crystals, type 2b-polyphase inclusions with two salt crystals in crystal growth zones, type 3 - brine inclusions with one salt crystal in crystal growth zones, type 4 - vapourrich inclusions, type 5 - primary inclusions in anhydrite, and types 6 and 7 - secondary lowtemperature inclusions This research suggests that saline fluids (30-40\% wt.\% $\mathrm{NaCl}$ eq.) were the most important ones for the formation of porphyry-type mineralization and that the mineralization was formed at temperatures between 350 and $450^{\circ} \mathrm{C}$ and pressures between 100 and 500 bars. The epithermal stage was characterized by cooler low-salinity fluids with temperatures between $150-350^{\circ} \mathrm{C}$, and salinity between 0 and $7 \mathrm{wt} . \% \mathrm{NaCl}$ eq.
\end{abstract}

\section{INTRODUCTION}

Čukaru Peki is a copper-gold ore deposit, discovered in 2012 by Rakita Exploration, $5 \mathrm{~km}$ south of the mining town of Bor in eastern Serbia (JELENKOVIĆ, 2014). BANJEŠEVIĆ \& LARGE (2014) state that this ore deposit can be genetically classified as a high-sulphidation epithermal and porphyry copper-gold deposit.

This ore deposit belongs to the Bor metallogenic zone, which is spatially and genetically related to the Timok magmatic complex (JANKOVIĆ, 1990). This complex is around $85 \mathrm{~km}$ long. It is elongated in an approximate N-S direction and stretches from the town of Majdanpek in the north to Tupiznica mountain in the south. It is part of the eastern segment of the Cretaceous magmatic and metallogenic arc named the Apuseni-Banat-TimokSrednogorje belt, which was formed during the closure of the Neotethyan ocean (e.g., NEUBAUER, 2002; GALLHOFER et al., 2015). Magmatism in the Timok complex lasted for around $10 \mathrm{Ma}$, beginning in the Upper Turonian and ending in the Upper Campanian (CLARK \& ULLRICH, 2004; KOLB et al., 2013). However, it is generally accepted that most porphyry and epithermal ore deposits in this complex were formed in a considerably shorter period from $90 \mathrm{Ma}$ until $85 \mathrm{Ma}$ (JELENKOVIĆ et al., 2016, BANJEŠEVIĆ et al., 2019). A simplified geological map of the Timok magmatic complex with the locations of major ore deposits is illustrated in Fig.1.

Mineralization at Čukaru Peki is located near the villages of Brestovac and Metovnica at depths between 400 - >2000 m below the surface. It is hosted by altered Upper Cretaceous volcanic and volcaniclastic rocks named as the Lower andesite by Rakita exploration. They are overlain by a relatively unaltered andesitic unit, which varies in thickness from a few metres up to approximately $50 \mathrm{~m}$; this volcanic unit is named the Upper andesite. The
Upper andesite unit is covered by a westwardly dipping Upper Cretaceous sedimentary sequence of marls, sandstones, and conglomerates. The entire volcano-sedimentary succession is unconformably overlain by Miocene conglomerates and sandstones. The Miocene sediments dip at a low angle to the east and their thickness varies from $200-400 \mathrm{~m}$ in the Čukaru Peki area. (BANJEŠEVIĆ et al., 2019).

To date, there have been a few fluid inclusion studies on samples from the Bor metallogenic zone. STRASHIMIROV (1997) conducted fluid inclusion microthermonetry analysis on quartz samples from the nearby Majdanpek porphyry deposit and concluded that the hydrothermal processes started in this system at temperatures higher than $580^{\circ} \mathrm{C}$, which was followed by separation of high-salinity brines and low-salinity vapour within a temperature range of $550-450^{\circ} \mathrm{C}$. It was also determined that the boiling of fluids has continued with decreasing temperature to about $400^{\circ} \mathrm{C}$, when the hydrothermal system was opened. This led to the increase in influence of meteoric water and a decrease in temperature and salinity, which propagated the precipitation of ore minerals. Later, KOŽELJ (2002) performed fluid inclusion studies on quartz, anhydrite and barite from the Bor epithermal zone and recognized the activity of medium-temperature fluids (150$250^{\circ} \mathrm{C}$ ) with salinities of $2-14 \mathrm{wt} . \% \mathrm{NaCl}$ eq. and low-temperature fluids $\left(130-220^{\circ} \mathrm{C}\right)$ with low salinities $(<5 \%$ wt. $\% \mathrm{NaCl}$ eq.). Also, BAILLY et al. (2002) performed infrared microthermometry on opaque minerals (enargite and sphalerite) from the Bor epithermal zone and concluded that the fluids had temperatures in the range of $163-240^{\circ} \mathrm{C}$ and salinities ranging between 4.65 and 8.41 wt. $\% \mathrm{NaCl}$ eq.

Here, we report and discuss the new results obtained by conventional petrography and microthermometry in samples from Čukaru Peki. This research is aimed at better constraining the 


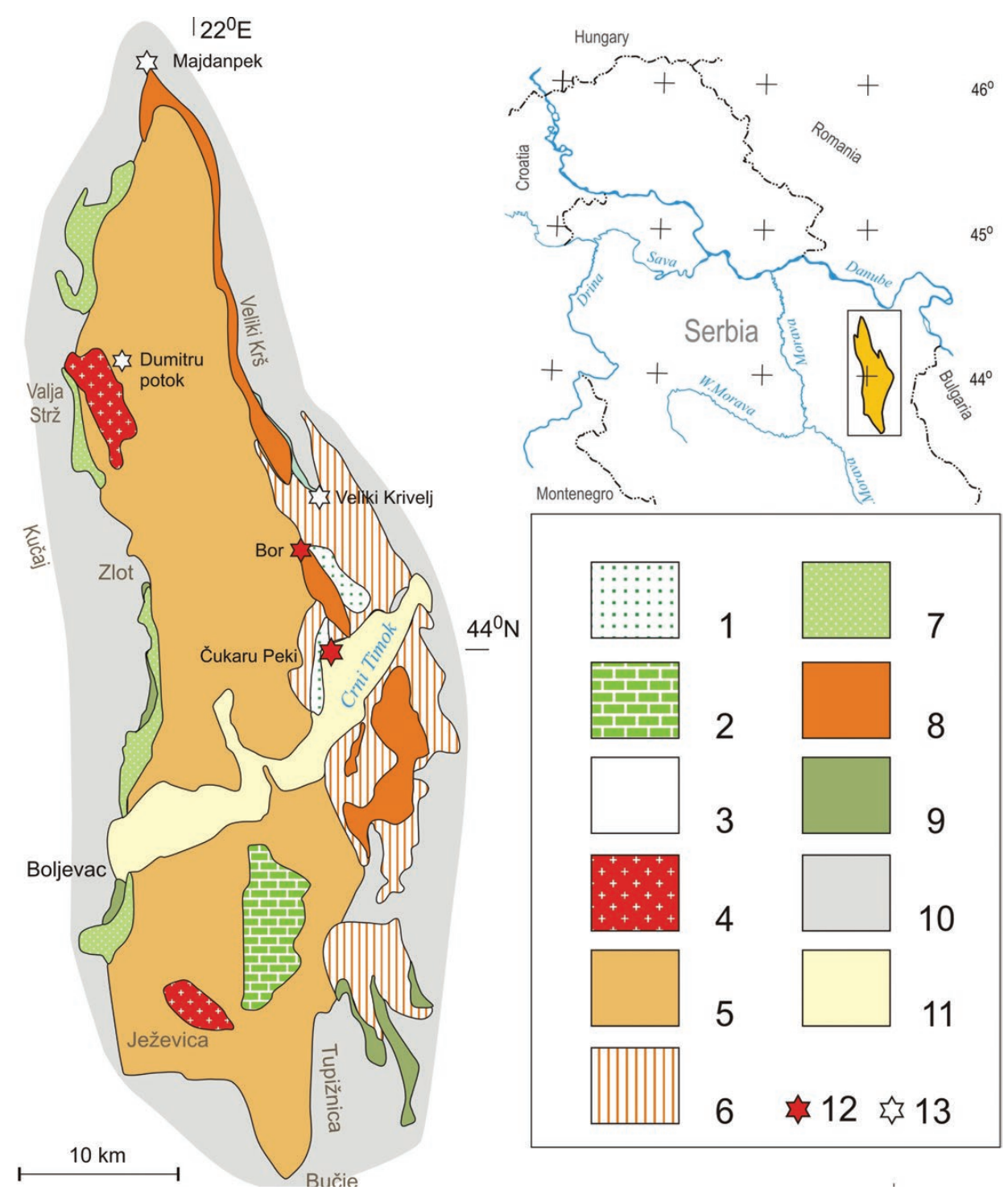

Figure 1. A simplified geological map of the Timok magmatic complex showing the location of the Čukaru Peki Cu-Au deposit. Legend: 1. Bor clastites, 2. Vrbovac reef, 3. Boljevac latite, 4. Valja Strž plutonite, 5. Osnić basaltic andesite and Ježevica andesite, 6. Metovnica epiclastite, 7. Oštrelj sediments, 8. Timok andesite, 9. Lenovac clastites, 10. TMC basement rocks, 11. Neogene and Quaternary sediments, 12. Porphyry Cu-Au and high sulphidation epithermal Cu-Au mineralization, 13. Porphyry Cu-Au deposit. (Modified from JELENKOVIĆ et al., 2016)

physico-chemical conditions that prevailed during the evolution of ore fluids at Čukaru Peki and illuminating the processes that led to the formation of this ore deposit.

\section{GEOLOGY OF THE DEPOSIT}

A simplified geological map of Čukaru Peki area with the locations of the studied drillholes is shown in Fig. 2 and a simplified cross-section through the Čukaru Peki ore deposit showing zones of different types of mineralization is illustrated in Fig. 3. According to JELENKOVIĆ et al. (2016) three major types of mineralization occur at Čukaru Peki as follows:

1) High sulphidation type - with a copper and gold-rich massive-sulphide ore body, which is roughly ellipsoid-shaped, with a horizontal area of $300 \times 300 \mathrm{~m}$ veins and a vertical length of 500-600 metres. The upper part of this ore body forms a rich apical zone, with more than $9 \% \mathrm{Cu}$. Going from the apical zone downward, the type of mineralization gradually changes to veins, disseminations and hydrothermal breccias. High sulphidation mineralization forms a zone, defined by intense alteration of the host rocks and pyritization at depths from $400 \mathrm{~m}$ to around $1000 \mathrm{~m}$ below the surface. The predominant sulphide minerals are covellite, pyrite, and enargite. The dominant alteration in this zone is advanced argillic (with quartz, alunite and dickite). There are several different types of hydrothermal breccias in the high sulphidation zone, but most ore-bearing breccias have fine-grained pyrite as fragments, with covellite, quartz or enargite in the matrix. The main copper-bearing minerals in the high-sulphidation zone are covellite and enargite, while recent measurements have shown that most of the gold in this zone is precipitated in the form of submicroscopic invisible gold in copper-bearing pyrite. (VELOJIC \& ERLANDSSON, 2019)

2) Transitional epithermal type - located between the porphyry and high sulphidation zones. In this type, epithermal covellite and enargite replace the primary sulphide (chalcopyrite) from porphyry mineralization. Most common veins in this zone are gypsum-, anhydrite-, and calcite veins, while the most common alteration is argillic (with kaolinite and/or montmorillonite).

3) Porphyry type - mostly hosted in diorite porphyries and overlying andesites at depths below $1000 \mathrm{~m}$ from the surface. Mineralization is mostly hosted by anhydrite and quartz veins 


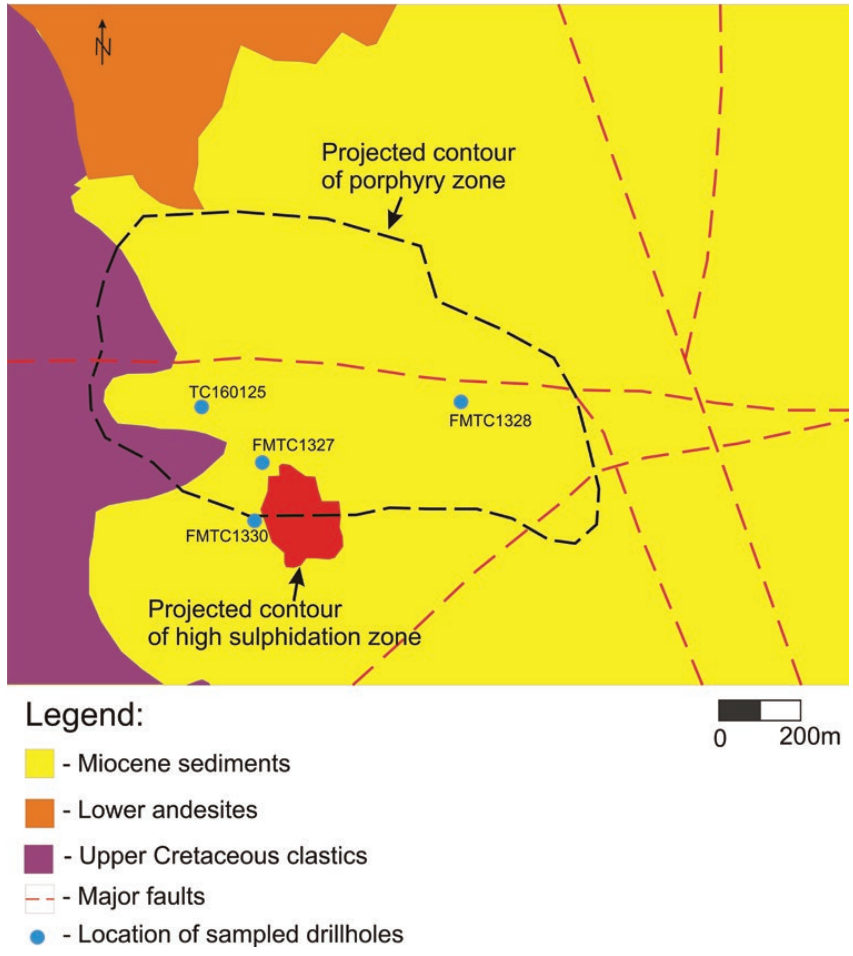

Figure 2. Simplified geological map of the Čukaru Peki area with projected contours of high sulphidation and porphyry zones, major faults and sampled drill holes, modified from NI 43-101 Preliminary economic assessment of the Čukaru Peki upper zone deposit, 2016. and the main ore minerals are chalcopyrite, pyrite, bornite, magnetite, and pyrrhotite, whereas the main alteration style is potassic (with K-feldspar and biotite). The main copper-bearing mineral in this zone is chalcopyrite, while gold is mostly precipitated as small grains of native gold and electrum in quartz veins.

The types of veins in the porphyry zone of Čukaru Peki generally fit into the classification scheme of veins in porphyry deposits described in SILLITOE (2010). Different types of veins in the porphyry zone of Čukaru Peki are illustrated in Fig. 4, while the paragenetic sequence is illustrated in Table 1. The assumed chronological order of the precipitation of veins at Čukaru Peki, based on the cross-cutting relationships of the veins, is as follows:

1) Quartz A veins. (Fig. 4a). Wiggly thin quartz veins in early diorite porphyries. These veins do not contain ore mineralization.

2) Quartz B veins. (Fig. 4a). They are stockwork quartz veins with chalcopyrite bands in the middle parts, commonly present in early diorite porphyries and the overlying andesite. The main ore mineral is chalcopyrite, whereas bornite and pyrite are subordinate.

3) Pyrite D veins (Fig. 4b). These veins are composed of relatively coarse-grained aggregates of pyrite accompanied by smaller amounts of chalcopyrite, bornite and rutile.

4) Magnetite M veins (Fig. 4c). They always occur in deeper parts of the porphyry system. The main minerals in these veins are magnetite and hematite, accompanied by subordinate pyrite, pyrrhotite and chalcopyrite.
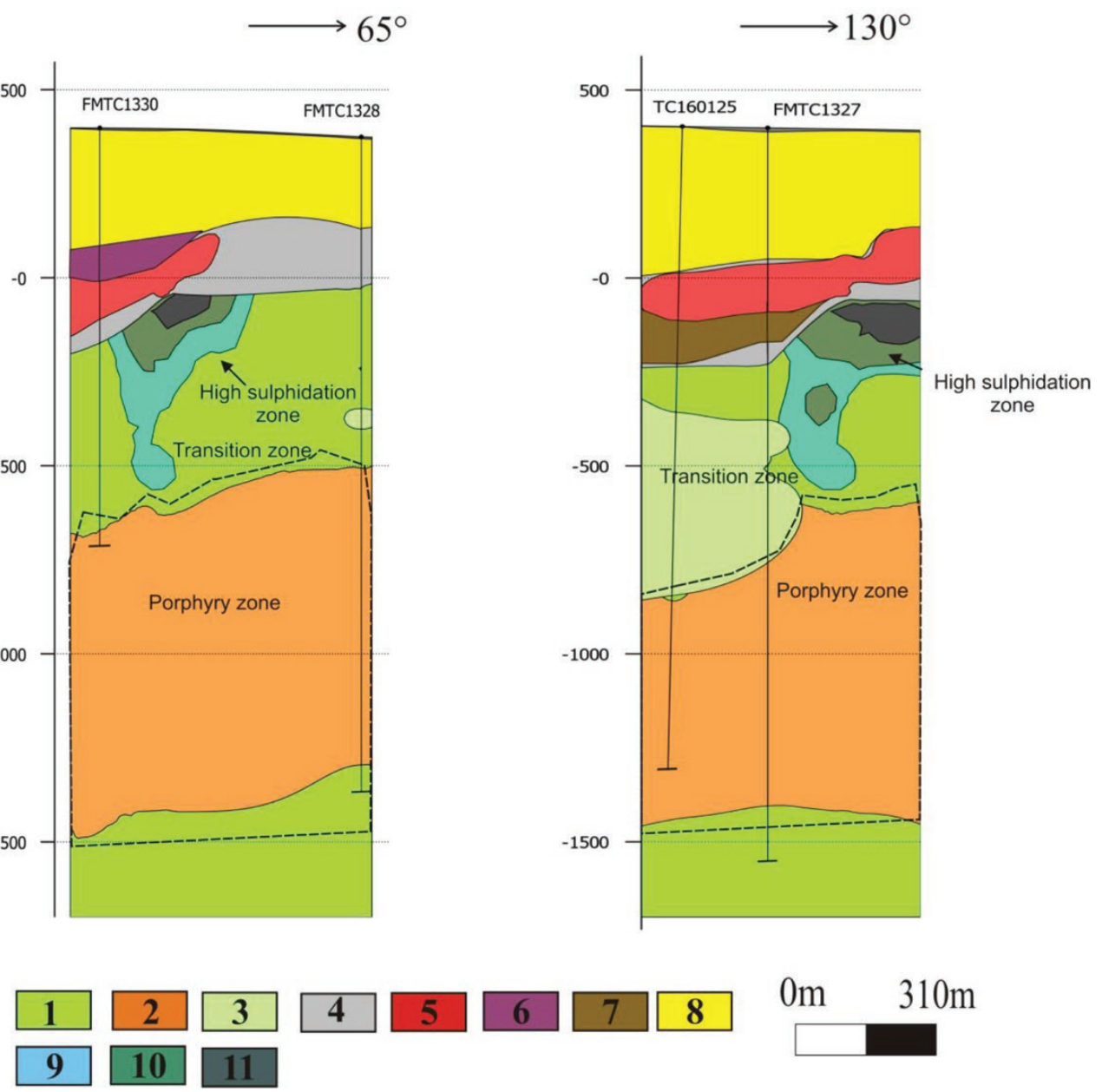
Table 1. Paragenetic sequence of veins in the porphyry zone of Čukaru Peki.

\begin{tabular}{|c|c|c|c|c|}
\hline & $\begin{array}{l}\text { Quartz } \\
\text { veins }\end{array}$ & $\begin{array}{l}\text { Magnetite } \\
\text { veins }\end{array}$ & $\begin{array}{l}\text { Purple anhydrite } \\
\text { veins }\end{array}$ & $\begin{array}{l}\text { Sulphide } \\
\text { veins }\end{array}$ \\
\hline Pyrite & & & & \\
\hline Chalcopyrite & & & & \\
\hline Bornite & & & & \\
\hline Magnetite & & & & \\
\hline Hematite & & & & \\
\hline Pyrrhotite & & 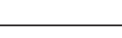 & & \\
\hline Rutile & & & & \\
\hline Covellite & & & & \\
\hline Enargite & & & & \\
\hline Gold & & & & \\
\hline
\end{tabular}
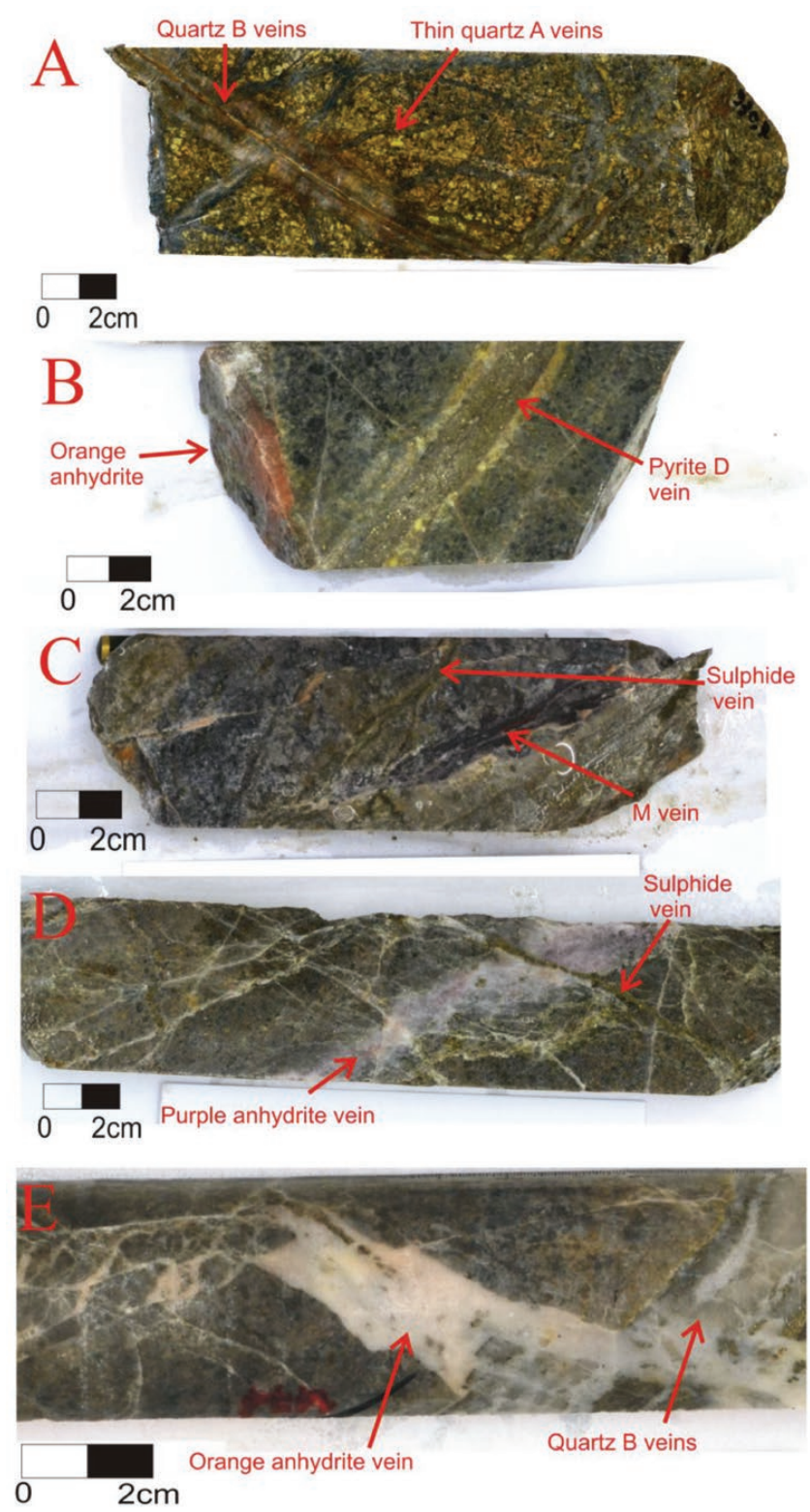

Figure 4. Types of veins in the porphyry zone of Čukaru Peki: A) Quartz B vein crosscutting smaller quartz A veins in diorite FMTC1328 930.7m; B) Sample with pyrite $D$ vein and thin orange anhydrite vein FMTC1328 1581,5m C) Thin sulphide vein crosscutting magnetite vein FMTC1327 1350m $\quad$ D) Thin sulphide vein crosscutting a purple anhydrite vein FMTC1328 1589m 1139.7m;E) Orange anhydrite vein crosscutting an earlier quartz B vein FMTC1327 1474m.
5) Purple anhydrite veins. (Fig. 4d). These veins are very common in the porphyry zone and in the transitional epithermal zone. They contain pyrite as the main mineral, with smaller amounts of chalcopyrite and bornite or covellite and chalcocite, depending on the position in the system.

6) Sulphide veins. (Fig. 4c and Fig. 4d) These veins are also quite common in the porphyry zone and in the transitional porphyry-epithermal zone. The main ore minerals in these veins are pyrite and covellite, while the main gangue minerals are anhydrite and alteration clay (probably kaolinite). The main distinguishing feature of these veins is that they commonly contain covellite and crosscut all of the previous vein types.

7) Orange anhydrite veins. (Fig. 4e). They are late veins, which do not contain ore minerals, and as such, they are easily distinguished from the purple anhydrite veins.

\section{SAMPLES AND METHODS}

The high-sulphidation zone of Čukaru Peki does not contain transparent minerals suitable for conventional fluid inclusion analysis since most of the gangue minerals present are too finegrained to be studied (e.g. BODNAR et al., 2014). Some sulphide minerals, including pyrite and enargite, could be used for infrared fluid inclusions analysis, which has already been applied on samples from this metallogenic zone (BAILLY et al., 2002). The current research focuses on veins with transparent minerals from porphyry and transitional porphyry-epithermal zones.

Samples for analysis were selected from relatively coarsegrained quartz A and B veins, purple anhydrite veins and orange anhydrite veins. Only one of the analyzed samples (CP069) was taken from the transition porphyry-epithermal zone, whereas all of the other samples were taken from the porphyry zone.

Transmitted-light petrography was performed on 12 doublepolished sections from 4 drill holes from the different zones of Čukaru Peki: FMTC1327, FMTC1328, FMTC1330 and TC160125.

A total of 106 separate inclusions were measured during this research. All microthermometric measurements were performed in the Fluid inclusion laboratory at the Faculty of Mining and Geology, Belgrade. Measurements were carried out on a THMSG600 heating stage connected to an Olympus BX51 microscope. The maximum heating temperature of inclusions on this device is $600^{\circ} \mathrm{C}$ and some of the analyzed inclusions did not reach total homogenization below this temperature. The primary $\mathrm{CO}_{2}$ standard WRECT-006160 was used for calibration.

PVTX properties (salinity, pressure, density) of measured fluid inclusions were calculated using HOKIEFLINCS-H20NACL excel spreadsheet (STEELE-MACINNIS et al., 2012), based on the total homogenization temperature of the inclusions and ice melting temperatures (for unsaturated inclusions) or salt dissolution temperatures (for saturated inclusions with one or more salt crystals). Salinities of brines were calculated by halite dissolution temperatures using equations by STERNER et al. (1988), salinities of low-salinity inclusions were calculated by ice melting temperatures using equations by BODNAR (1993), while the salinities of inclusions that homogenize by salt dissolution were determined by equations provided by LECUMBERRISANCHEZ et al. (2012). Data for the pressure calculation of boiling fluids were calculated in AqSo_NaCl software (BAKKER, 2018), based on equations by HAAR (1984) and DRIESNER \& HEINRICH (2007).

The information from the analyzed samples is summarized in Table 2, including not only the number of analyzed inclusions 
Table 2. Summary data for fluid inclusion analysis. For many inclusions, salinities were not measured due to their small size.

\begin{tabular}{|c|c|c|c|c|c|c|c|c|c|c|c|}
\hline Vein type & Samples & $\begin{array}{l}\text { Fluid } \\
\text { inclusion } \\
\text { type }\end{array}$ & $\begin{array}{c}\text { Mode of } \\
\text { homogenization }\end{array}$ & $\begin{array}{l}\text { Number of } \\
\text { analyzed } \\
\text { inclusions }\end{array}$ & $\begin{array}{l}\text { Sample } \\
\text { depth }\end{array}$ & $\begin{array}{c}\text { Th } \\
\text { (Mean } \pm \text { std) }\end{array}$ & $\mathrm{Th}(\mathrm{min})$ & Th(max) & Tm (phase) & Tm (mean) & $\begin{array}{c}\text { Salinity } \\
\text { (Mean } \pm \text { std) }\end{array}$ \\
\hline \multirow[t]{2}{*}{ Quartz A } & $\begin{array}{c}\text { CP105, } \\
\text { CP106, } \\
\text { CP123, } \\
\text { CP141, CP143 }\end{array}$ & 1 & $\mathrm{LSV} \rightarrow \mathrm{LV} \rightarrow \mathrm{L}$ & 7 & $930-1693 m$ & $\begin{array}{c}580 \pm 20.35 \\
\text { (for inclusions } \\
\text { with } T h<600 \text { ) }\end{array}$ & 545.8 & $>600$ & halite & 268.8 & $35.6 \pm 5.2$ \\
\hline & & 4 & $\mathrm{LV} \rightarrow \mathrm{V}$ & 3 & $1622 m$ & $396 \pm 20$ & 389 & 428 & & & \\
\hline \multirow[t]{5}{*}{ Quartz B } & $\begin{array}{c}\text { CP089, } \\
\text { CP096, } \\
\text { CP105, } \\
\text { CP106, CP116 }\end{array}$ & 2 & $\mathrm{LSV} \rightarrow \mathrm{LS} \rightarrow \mathrm{L}$ & 5 & 930-1796m & $350 \pm 12.8$ & 326 & 356 & halite & 350 & $43 \pm 1.2$ \\
\hline & & 2 & $\mathrm{LSV} \rightarrow \mathrm{LV} \rightarrow \mathrm{L}$ & 2 & $930 \mathrm{~m}$ & $442 \pm 40$ & 414 & 470 & halite & 359 & $43 \pm 0.6$ \\
\hline & & 3 & $\mathrm{LSV} \rightarrow \mathrm{LV} \rightarrow \mathrm{L}$ & 11 & 930-1796m & $385 \pm 50.3$ & 342 & 495 & halite & 278.7 & $36.5 \pm 3.1$ \\
\hline & & 4 & $\mathrm{LV} \rightarrow \mathrm{L}$ & 7 & 1447-1796m & $387 \pm 26.7$ & 331 & 413 & & & \\
\hline & & 7 & $\mathrm{LV} \rightarrow \mathrm{L}$ & 8 & $930-1447 m$ & $117.5 \pm 26.4$ & 69.2 & 161 & & & \\
\hline \multirow[t]{2}{*}{$\begin{array}{l}\text { Purple } \\
\text { anhydrite }\end{array}$} & $\begin{array}{l}\text { CP069,CP108, } \\
\text { CP110, CP123 }\end{array}$ & 5 & $\mathrm{LV} \rightarrow \mathrm{L}$ & 37 & $1080-1610 \mathrm{~m}$ & $298 \pm 37.2$ & 225 & 396 & ice & -2.3 & $3.87 \pm 2.1$ \\
\hline & & 6 & $\mathrm{LV} \rightarrow \mathrm{L}$ & 16 & $1080-1610 \mathrm{~m}$ & $200 \pm 41.8$ & 131 & 291.7 & ice & -2.3 & $3.87 \pm 1.5$ \\
\hline $\begin{array}{l}\text { Orange } \\
\text { anhydrite }\end{array}$ & CP108, CP141 & 7 & $\mathrm{LV} \rightarrow \mathrm{L}$ & 8 & $1116-1622 m$ & $89.6 \pm 27.3$ & 73 & 138.5 & ice & -2.65 & $4.4 \pm 0.3$ \\
\hline
\end{tabular}

in the different types of veins, but also the depth of samples, modes of homogenization and the obtained average homogenization temperatures and salinities. A raw data table with all the measurements is provided in the Appendix.

\section{RESULTS}

\subsection{Types of fluid inclusions}

Several types of fluid inclusion assemblages (FIAs) were distinguished in veins in the porphyry zone of Čukaru Peki. According to GOLDSTEIN \& SAMSON (2003), a fluid inclusion assemblage comprises a discriminated group of petrographically associated fluid inclusions, which are assumed to be trapped coevally. Criteria for the determination of primary fluid inclusions includes inclusions which are trapped along the growth zones of minerals or inclusions which are randomly scattered throughout a quartz crystal (ROEDDER, 1984; GOLDSTEIN \& SAMSON, 2003, MAO et al., 2017). If such a group of fluid inclusions with similar phase proportions at room temperature yields similar melting and homogenization temperatures, it is inferred that they belong to a primary assemblage. On the other hand, secondary fluid inclusion assemblages are aligned in planar arrays or along curved surfaces that crosscut crystal growth zones. (GOLDSTEIN \& SAMSON, 2003) It should be noted that precise genetic determination of fluid inclusion assemblages in minerals in porphyry systems, by specific orientation in a mineral growth zone, or by alignment in planar arrays in crystals, is rarely straightforward because of the presence of numerous healed fractures and growth zones. (JOHN et al., 2010) Photomicrographs of different fluid inclusion assemblages are shown in Figure 5 and zoomed photomicrographs of individual inclusions are shown in Figure 6.

Three different associations of fluid inclusions are distinguished in the studied quartz veins from Čukaru Peki:

1) Primary association 1: (type 1) Primary three-phase inclusions (gas + liquid \pm halite) (Fig. 6a). The criterion for the identification of these fluid inclusions as petrologically primary is the fact that they were trapped in crystal growth zones in quartz veins (as seen on fig. 5a and fig. 5d). These inclusions often have a negative-crystal shape and they contain a relatively large bubble; phase composition at room temperature is: $>30 \% \mathrm{~V} \pm 10-20 \% \mathrm{~S}+$ $50-60 \% \%$ L. Most of these inclusions contain a small halite crystal, which implies they are probably high-temperature brines.

2) Brine association 1: (type 2a) Polyphase brine inclusions with two salt phases (gas + liquid +2 solid phases \pm hematite \pm opaque mineral) (Fig.6b). These inclusions are distinguished by the presence of 2 or more salt crystals. Considering the crystal habitus (cubic and anhedral), transparency and refractivity of the two salt crystals, they are assumed to be $\mathrm{NaCl}$ and $\mathrm{KCl}$ crystals. These salts are also the most common solid phases in brine inclusions in porphyry deposits (ROEDDER, 1984; WILKINSON, 2001; LECUMBERRI-SANCHEZ et al., 2012). These inclusions are commonly found in same quartz crystals as type $2 \mathrm{~b}$ and type 3 inclusions, but in most cases, they are scattered in quartz crystals (fig. $5 \mathrm{~b}$ and fig. fig. $5 \mathrm{~d}$ ). Phase composition at room temperature is: $20 \% \mathrm{~V}+30-40 \% \mathrm{~S}+40-50 \% \mathrm{~L}$.

3) Brine association 2: This association contains three different types of inclusions:

Type 2b: Polyphase brine inclusions with two salt phases (gas + liquid +2 solid phases \pm opaque mineral \pm hematite). These inclusions are quite similar to type $2 \mathrm{a}$, but they are larger and they appear in the same quartz growth zones as type 3 inclusions.

Type 3: Polyphase brine inclusions with only one salt crystal (gas + liquid + halite \pm opaque mineral) (Fig. 6c). The opaque mineral in these inclusions was not identified by other methods, but according to its habitus and the mineral composition of veins, it is likely that it is chalcopyrite. As for the previous type, these inclusions occur either in quartz growth zones or in clusters in quartz veins (fig. $5 \mathrm{~b}$ and fig. $5 \mathrm{c}$ ). They commonly occur in the same assemblages as type $2 \mathrm{~b}$ and type 4 inclusions. Phase composition at room temperature is: $20 \% \mathrm{~V}+20-30 \% \mathrm{~S}+50-60 \% \mathrm{~L}$.

Type 4 (Fig. 6d): Apparently single-phase dark vapour-rich inclusions are usually small and they are common in most of the analyzed quartz samples. The apparent single phase appearance does not exclude the presence of a thin liquid film along the walls of the inclusions. These commonly occur in similar assemblages to the type $2 \mathrm{~b}$ and type 3 inclusions (fig. $5 \mathrm{c}$ ), but they are also sometimes randomly distributed throughout quartz crystals. 


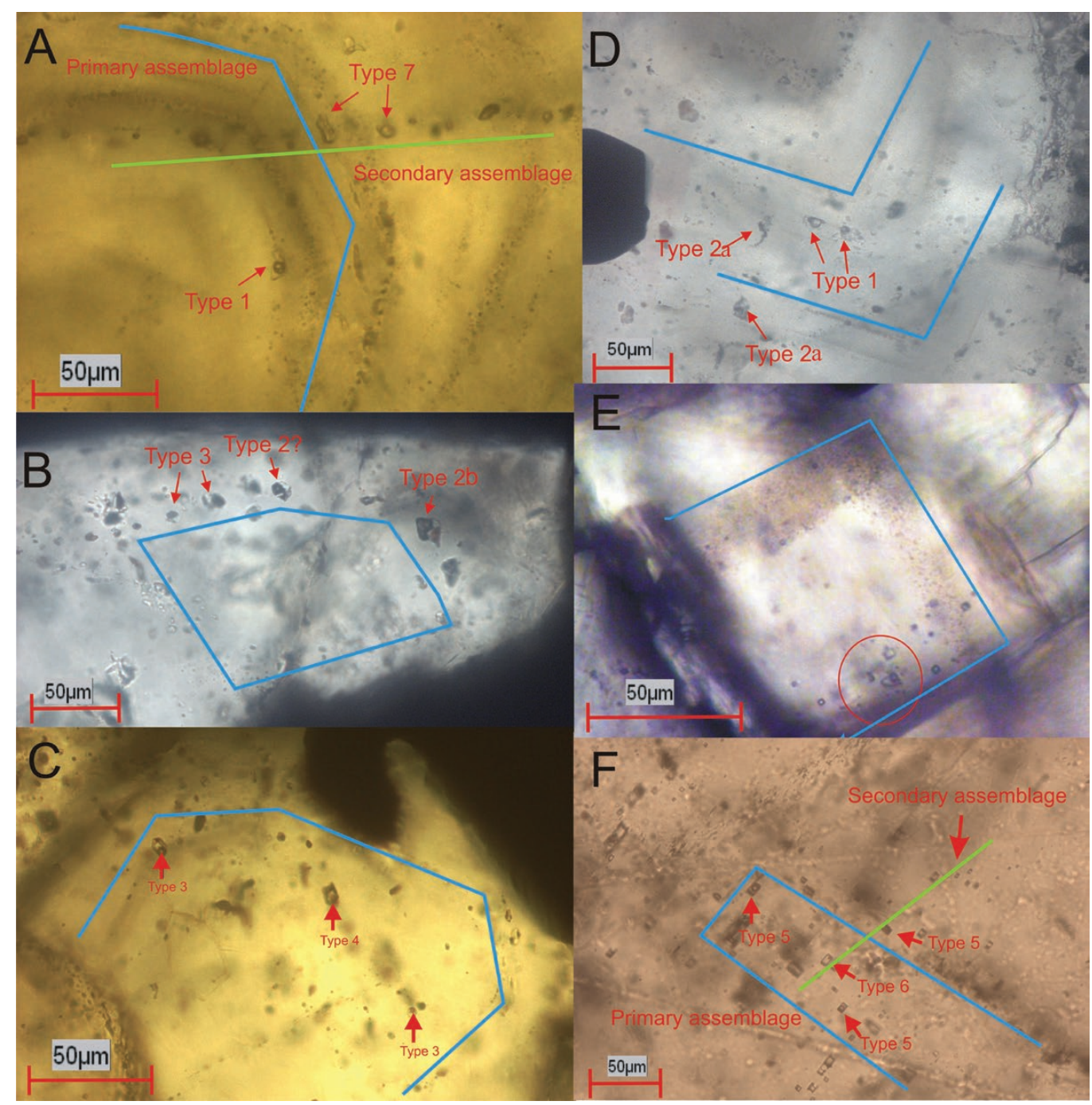

Figure 5. Types of fluid inclusion assemblages in veins in Čukaru Peki. Legend: A) Primary type 1 assemblage in growth zone in quartz, crosscut by secondary assemblage of type 7 inclusions FMTC1327 1315,5m; B) Brine association 2 with type $2 \mathrm{~b}$ and type 3 inclusions in growth zone in quartz B vein FMTC1328 953,7m; C) Brine association 2: type 3 inclusions with opaque mineral with type 4 vapour inclusions in quartz growth zone FMTC1327 1796,3m; D) Type 1 inclusions in growth zones in quartz vein and scattered type 2a inclusions FMTC1327 1315,5m; E) Primary assemblage of type 5 inclusions in square crystal of anhydrite FMTC1328 $1139,7 \mathrm{~m} ;$ F) Primary type 5 inclusions, crosscut by secondary aqueous type 6 inclusions in anhydrite FMTC1328 1610,5m. Orientations of primary assemblages are marked with blue lines, while the orientations of secondary inclusions are marked with a green line.

In purple anhydrite veins, two types of assemblages can be distinguished:

1) Type 5: Gaseous fluid inclusions in purple anhydrite (vapour + liquid \pm opaque mineral) (Fig. 6e). These inclusions are probably primary inclusions in anhydrite because they have negative square crystal shapes and follow the growth zones of the anhydrite crystals (fig. 5e and fig. 5f). Phase composition at room temperature is: $20 \% \mathrm{~V}+80 \% \mathrm{~L}$.

2) Type 6: Aqueous inclusions in anhydrite (vapour + liquid) (Fig. 6e) are probably secondary inclusions because they are scattered in anhydrite or they follow the directions of later cracks (fig. 5f). Their bubble is significantly smaller than type 5 inclusions- phase composition at room temperature is: $5-10 \% \mathrm{~V}+90$ $95 \% \mathrm{~L}$.

Beside these types, there are also assemblages of secondary inclusions, which are present both in quartz veins and in orange anhydrite veins:

Type 7: Late aqueous inclusions (vapour + liquid \pm opaque mineral) are secondary inclusions. (Fig. 6f). It is assumed that these are low temperature inclusions, since the bubble is very small, phase composition at room temperature is: $5-10 \% \mathrm{~V}+90$ $95 \% \mathrm{~L}$. These inclusions are common in most of the analyzed samples, especially in quartz veins and orange anhydrite veins. These inclusions are often in linear assemblages which follow the directions of late cracks. (fig.5a) Present opaque minerals were not identified, but their elongated habitus is quite different from the opaque minerals in type $2 \mathrm{a}, 2 \mathrm{~b}$ and type 3 inclusions.

\subsection{Microthermometric results}

Some of the recognized fluid inclusion assemblages were not adequate for microthermometric measurements, due to the small size of the present inclusions $(<5 \mu \mathrm{m})$, which hinders the visual recognition of phase transitions. This problem was especially present while measuring type 4 inclusions. Also, fluid inclusions that appear to be leaked and the inclusions that display "necking down" features were not measured by microthermometry in order to avoid the impact of reequilibration processes. (ROEDDER, 1984; BODNAR \& SAMSON, 2003)

Generally speaking, there are four different modes of homogenization of analyzed fluid inclusions from Čukaru Peki: 
$\mathrm{LSV} \rightarrow \mathrm{LV} \rightarrow \mathrm{L}, \mathrm{LSV} \rightarrow \mathrm{LS} \rightarrow \mathrm{L}, \mathrm{LV} \rightarrow \mathrm{V}$ and $\mathrm{LV} \rightarrow \mathrm{L}$. Total homogenization occurs over a very wide range of temperatures, from less than $100^{\circ} \mathrm{C}$ to more than $600^{\circ} \mathrm{C}$, and the salinity of the inclusions is quite variable (0-44 wt.\% $\mathrm{NaCl}$ eq.), which is also reported in many other porphyry deposits worldwide (e.g. BODNAR et al., 2014). Frequency distribution diagrams of the measured homogenization temperatures and salinities of different types of inclusions are presented in Fig. 7.

Primary association (type 1) inclusions are probably formed at very high temperatures because most of them did not homogenize at $600^{\circ} \mathrm{C}$, which is the limit of the heating stage employed. Only three of the measured fluid inclusions reached total homogenization at 546,580 and $582^{\circ} \mathrm{C}$. The mode of homogenization for all of these inclusions was: $\mathrm{LSV} \rightarrow \mathrm{LV} \rightarrow \mathrm{L}$. Salinities of these inclusions were determined by halite dissolution temperatures and they vary from 30 to $44 \mathrm{wt} . \% \mathrm{NaCl}$ eq.

Homogenization temperatures of type $2 \mathrm{a}$ inclusions are between 320 and $470^{\circ} \mathrm{C}$, with mean values around $350^{\circ} \mathrm{C}$. The interesting feature of these brines is that they homogenize by halite dissolution, after the homogenization of the bubble $(\mathrm{LSV} \rightarrow \mathrm{LS} \rightarrow \mathrm{L}$ ). The common homogenization sequence of these inclusions starts with the first salt crystal dissolving between 150 and $200^{\circ} \mathrm{C}$, it is followed by homogenization of the bubble and ends by the sec- ond salt crystal dissolving, around $350-400^{\circ} \mathrm{C}$. The low melting temperature of the first salt crystal suggests these salt crystals are sylvite. This mode of homogenization excludes the trapping of these inclusions from boiling fluids. (LECUMBERRI-SANCHEZ et al., 2012).

However, two of the measured type $2 \mathrm{~b}$ inclusions homogenized by bubble homogenization, after the dissolution of salt crystals $(\mathrm{LSV} \rightarrow \mathrm{LV} \rightarrow \mathrm{L})$. Their homogenization temperatures were 414 and $470^{\circ} \mathrm{C}$. The inclusions which contain two salt crystals are modeled by $\mathrm{NaCl}-\mathrm{KCl}-\mathrm{H}_{2} \mathrm{O}$ system (ROEDDER, 1984), where the total salinity in fluid inclusions containing both $\mathrm{NaCl}$ and $\mathrm{KCl}$ crystals is calculated from the dissolution temperature of the first salt crystal that occurs at the cotectic line and the dissolution temperature of the second salt crystal, which is reflected by the isotherms in a specific field (BAKKER, 2012). Salinities for these inclusions are calculated by equations and cotectic lines given by STERNER et al. (1988).

Homogenization temperatures of type 3 inclusions are between 340 and $490^{\circ} \mathrm{C}$, with mean values around $380^{\circ} \mathrm{C}$, whereas their salinity ranges between 28 and 38 wt. $\% \mathrm{NaCl}$ eq. The mode of homogenization for all of these inclusions was: $\mathrm{LSV} \rightarrow \mathrm{LV} \rightarrow \mathrm{L}$. Homogenization of the opaque phase was not observed, which could be explained by hydrogen diffusion, which reduces the

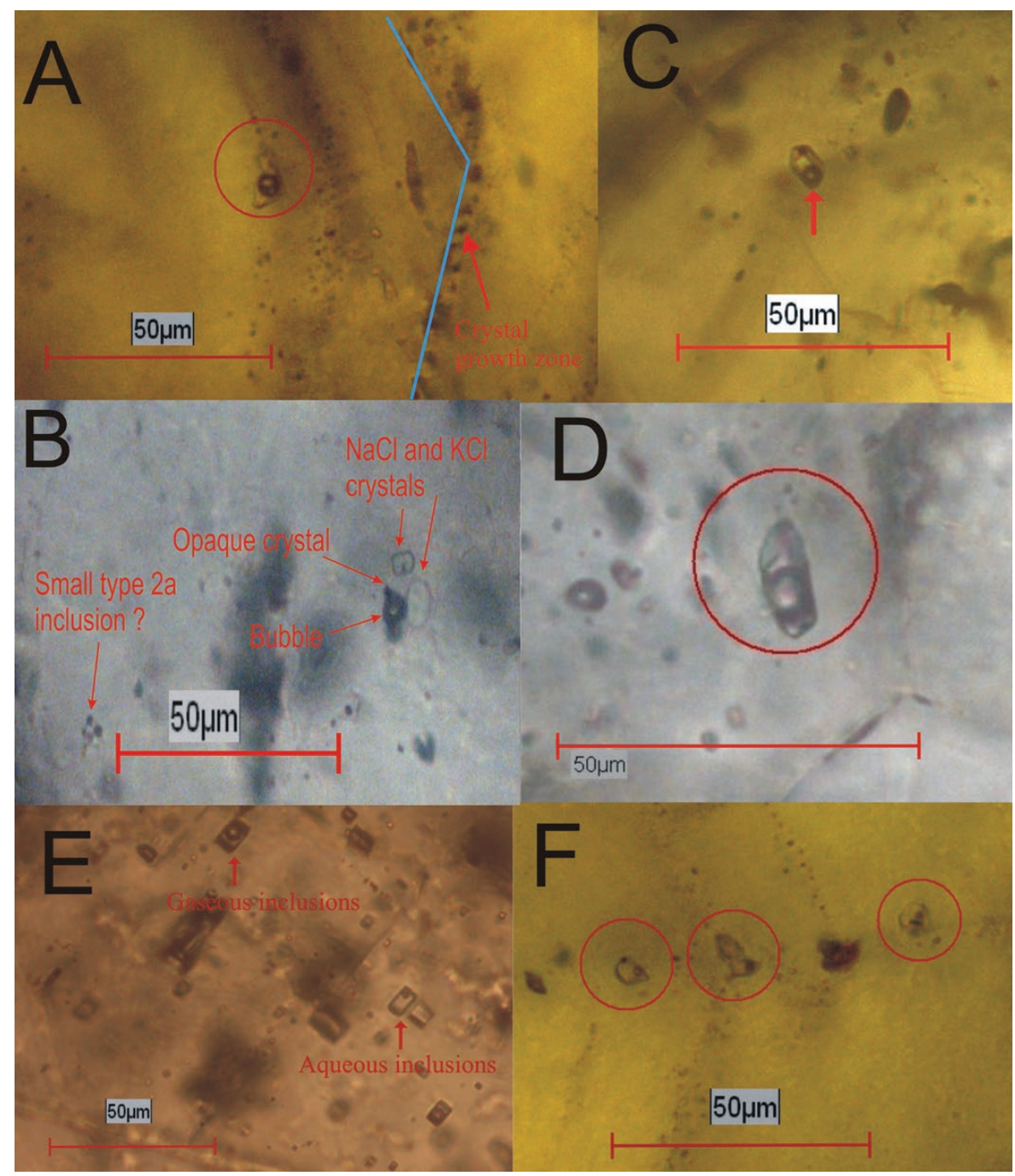

Figure 6. Zoomed photomicrographs of fluid inclusions in assemblages (at room temperature). Legend: A) Zoomed primary type 1 inclusions in growth zone in quartz, zoomed from Fig.5A; B) Polyphase type 2a inclusions with 2 salt crystals and opaque mineral in quartz FMTC1327 1315,5m; C) Type 3 inclusion with opaque mineral in quartz FMTC1327, zoomed from Fig.5C; D) Type 4 inclusion FMTC1328 1527m; E) Gaseous type 5 inclusions and aqueous type 6 inclusions in anhydrite, zoomed from Fig.5F; F) Secondary aqueous type 7 inclusions with small opaque phases, zoomed from Fig.5A 
solubility of the sulfide minerals in inclusions (MAVROGENES \& BODNAR, 1994).

Some of the measured type 4 inclusions homogenized to vapour $\left(\mathrm{LV} \rightarrow \mathrm{V}\right.$ at 389,428 and $\left.485^{\circ} \mathrm{C}\right)$, while the rest of them homogenized to liquid $(\mathrm{LV} \rightarrow \mathrm{V})$. The mean temperature of homogenization is around $390^{\circ} \mathrm{C}$. Due to their small size and dark appearance, suitable ice melting experiments were not possible, so their exact salinity is unknown. Given that there are no visible salt crystals, their salinity is most likely lower than $20 \mathrm{wt} . \% \mathrm{NaCl}$ eq.

Homogenization temperatures of type 5 inclusions vary between 245 and $396^{\circ} \mathrm{C}$, with a mean homogenization temperature of around $297^{\circ} \mathrm{C}$. The mode of homogenization for all of these inclusions was: $\mathrm{LV} \rightarrow \mathrm{L}$. Ice melting temperatures in these inclusions are between -0.5 and $-4.4^{\circ} \mathrm{C}$, which corresponds to salinities between 0.87 and 7 wt.\% NaCl eq. (BAKKER, 2018; according to equations by POTTER et al., 1978). It should be noted that most of the measurements on anhydrite crystals were only performed once, due to the phenomenon of thermal expansion of anhydrite during heating which may affect homogenization temperatures. Another problematic phenomenon which sometimes occurs is the stretching or decrepitation of the inclusions if they are heated above their homogenization temperature (VANKO \& BACH, 2005).

Homogenization of the opaque phase was not observed. The mode of homogenization for all of these inclusions was: $\mathrm{LV} \rightarrow \mathrm{L}$. Their salinities vary between 3 and $7.2 \mathrm{wt} . \% \mathrm{NaCl}$ eq. As for the previous type of inclusions, measurements were only performed once, to prevent the effects of the thermal expansion of anhydrite and the stretching of fluid inclusions .

Measured homogenization temperatures of the type 7 inclusions are between 73 and $161^{\circ} \mathrm{C}$, with mean values around $117^{\circ} \mathrm{C}$. The mode of homogenization for all of these inclusions was: $\mathrm{LV} \rightarrow \mathrm{L}$. The salinities of measured inclusions are between 4 and 5 wt.\% $\mathrm{NaCl}$ eq. Homogenization of the opaque phase was not observed.

\section{DISCUSSION}

Considering the occurrence of primary fluid inclusions in inner quartz growth zones (Fig. 5a and 5d), their high homogenization temperatures (usually above $600^{\circ} \mathrm{C}$ ) and high salinity (30-44 wt. $\% \mathrm{NaCl}$ eq.), it can be concluded that these fluid inclusion assemblages (classified as type 1) trapped the earliest fluids in this porphyry system. Similar inclusions have been recognized in other porphyry deposits worldwide and they are usually considered relicts of magmatic-hydrothermal fluids that are exsolved from the cooling magmatic body. These inclusions are usually found in the deeper parts of porphyry systems, where the pressure is sufficiently high to prevent boiling (REDMOND et al., 2004, RUSK et al., 2008).

The following stage in the fluid evolution of Čukaru Peki was marked by the trapping of brine inclusion assemblages with 2 or more solid phases (type 2a inclusions). The presence of polyphase inclusions with 2 salt crystals is not uncommon for porphyry systems (eg. WILKINSON, 2001), and the observed homogenization features imply that these fluids had a complex composition and high salinity ( $>40 \mathrm{wt} . \% \mathrm{NaCl}$ eq.) (LECUMBERRI-SANCHEZ et al., 2012). Considering the habitus, isotropic optical properties, low refractivity index of the second solid phase and its low dissolution temperature, it can be concluded that it is $\mathrm{KCl}$ (sylvite). The scattered distribution of these inclusions as well as their homogenization mode implies that these inclusions are not trapped by boiling fluids. This further implies that these inclusions trapped a K-rich fluid, which caused potassic alteration in the early porphyry stage. Occasionally, the presence of hematite in these inclusions implies that these fluids were also Fe-rich.

The coexistence of numerous vapour-rich inclusions (type 4) in the same quartz crystals as high-salinity brine assemblages (type $2 \mathrm{~b}$ and type 3 ) as an association is considered to be evidence of boiling in the system. (HEINRICH, 2005). According to LECUMBERRI-SANCHEZ et al. (2015), halite saturation in porphyry systems has important implications for the reduction of permeability in the system and promotes the precipitation of ore minerals. According to SILLITOE (2010), porphyry mineralization in shallow porphyry systems ( $<4 \mathrm{~km}$ deep) is the product of a two-phase fluid, commonly consisting of a small amount of highly saline liquid (brines) and a larger amount of low-salinity vapour. In these systems, the liquid phase is enriched in $\mathrm{Na}, \mathrm{K}$ and Fe chlorides, which results in high salinity $(35$ to $70 \mathrm{wt} . \% \mathrm{NaCl}$ eq.), while the vapour phase contains acidic volatiles, such as $\mathrm{SO}_{2}$, $\mathrm{CO}_{2}, \mathrm{H}_{2} \mathrm{~S}, \mathrm{HCl}$ etc. In Čukaru Peki, this highly saline liquid phase was trapped in brine inclusion assemblages (type $2 \mathrm{~b}$ and type 3 ), whereas the vapour phase was trapped in small type 4 inclusions throughout the same crystals. Considering the measured homogenization temperatures and halite melting temperatures of these three types of inclusions, it can be concluded that the process of boiling and separation of phases occurred at temperatures between 350 and $450{ }^{\circ} \mathrm{C}$, with fluid salinities of the brines between 30 and $40 \mathrm{wt} . \% \mathrm{NaCl}$ eq, which led to ore deposition.

The detection of the boiling of fluids enables the calculation of pressure in the system and the palaeodepth of ore-forming processes (FOURNIER, 1999; REDMOND et al., 2004; RUSK et al., 2008; MAO et al., 2017; LI et al., 2019). Pressure estimates for boiling fluids were calculated for halite-bearing inclusion assemblages (type $2 \mathrm{~b}$ and type 3 ). Brine inclusions which homogenized by halite dissolution were not included in the calculation, since they were not trapped from boiling fluids (LECUMBERRISANCHEZ et al., 2015). Calculated pressure estimates yielded values between 100 and 500 bar. According to the pressure/depths diagrams presented by FOURNIER (1999) and REDMOND et al. (2004) this pressure corresponds to fluctuations between lithostatic and hydrostatic pressure at palaeodepths between 1 and 2 kilometres . These pressure estimates are shown on the pressuretemperature diagram for $\mathrm{NaCl}-\mathrm{H}_{2} \mathrm{O}$ system in Figure 8 .

The conclusion that ore deposition in the porphyry zone of Cukaru Peki occurred at these temperatures is in accordance with fluid evolution studies in the nearby Majdanpek porphyry system (STRASHIMIROV (1997), but similar processes were also identified in other porphyry deposits. For example, HEINRICH et al. (2005) argue that ore deposition in porphyry copper deposits ideally happens around $400^{\circ} \mathrm{C}$ at low pressures, caused by the drop in solubility of $\mathrm{Cu}-\mathrm{Fe}$ sulphides. Also, ORLANDEA \& VLAD (2020) state that $\mathrm{Cu}-\mathrm{Au}$ porphyry systems are characterized by boiling of fluids between 500 and $400^{\circ} \mathrm{C}$ and pressures of 0.4 to $0.5 \mathrm{kbars}$. It is generally assumed that the separation of the initial fluid to high-salinity brines and low-salinity vapour (at depths between $2-4 \mathrm{~km}$ ) is followed by the rise of these fluids through the magma to the cupola zone (REDMOND et al., 2004; RICHARDS, 2005), which explains why these two types of fluids can be found at different levels vertically within the porphyry zone of Čukaru Peki.

As indicated in Figure 9, inclusion types 5, 6 and 7 have significantly lower salinities than early brines, so this implies that the transition to the epithermal stage happened by cooling and diluting of the fluids. According to SILLITOE (2010), in the later 


\section{Frequency of homogenization temperatures in different fluid inclusion \\ types}

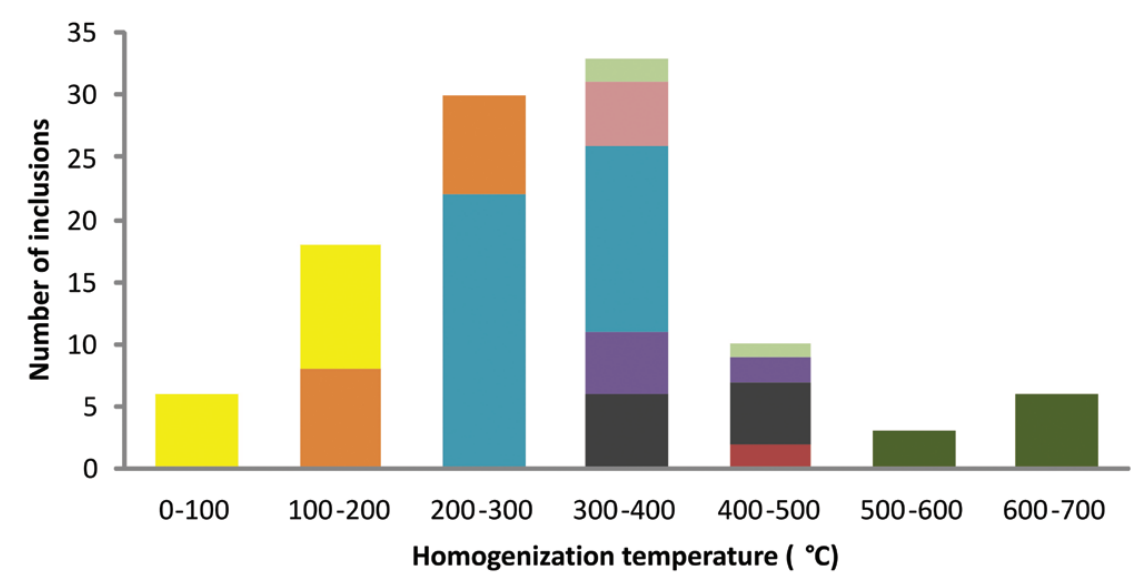

\section{Frequency of salinities in different fluid inclusion types}

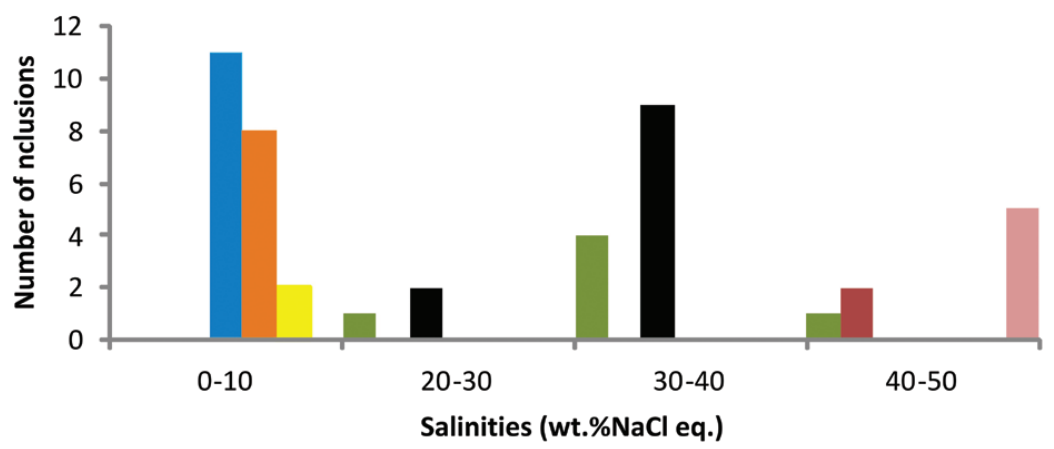

\section{$\square 1 \square 2 \mathrm{~b} \square 3 \square 4 \square 5 \square 6 \square 7 \square 2 \mathrm{a} \square 4 \mathrm{a}$}

Figure 7. Frequency distribution diagrams of measured homogenization temperatures and salinities of different types of fluid inclusions from Čukaru Peki. Type 2a refers to brine inclusions which homogenize by halite dissolution, while 4a refers to inclusions type 4 which homogenize to vapour.

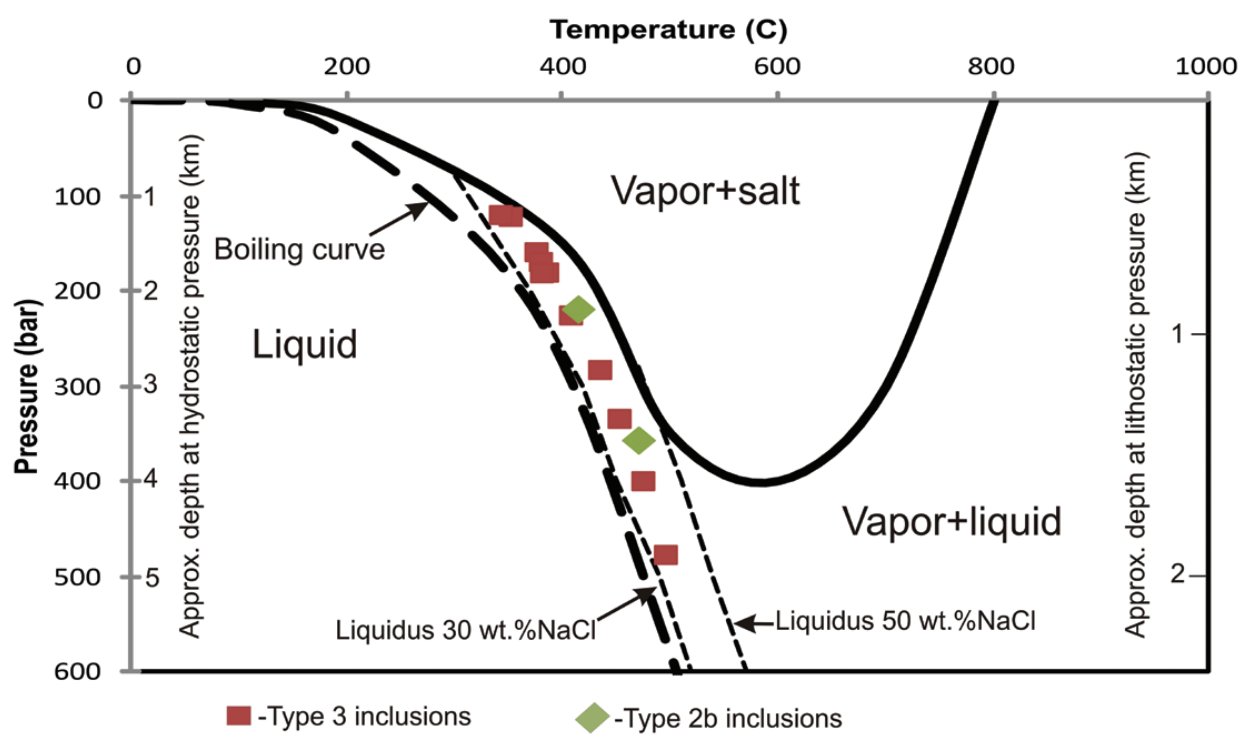

Figure 8. Pressure-temperature diagram for $\mathrm{NaCl}_{2} \mathrm{H}_{2} \mathrm{O}$ system (modified from FOURNIER, 1999 and REDMOND et al., 2004) showing pressure estimates for brine fluid inclusions (type $2 \mathrm{~b}$ and type 3 ) from Čukaru Peki. 


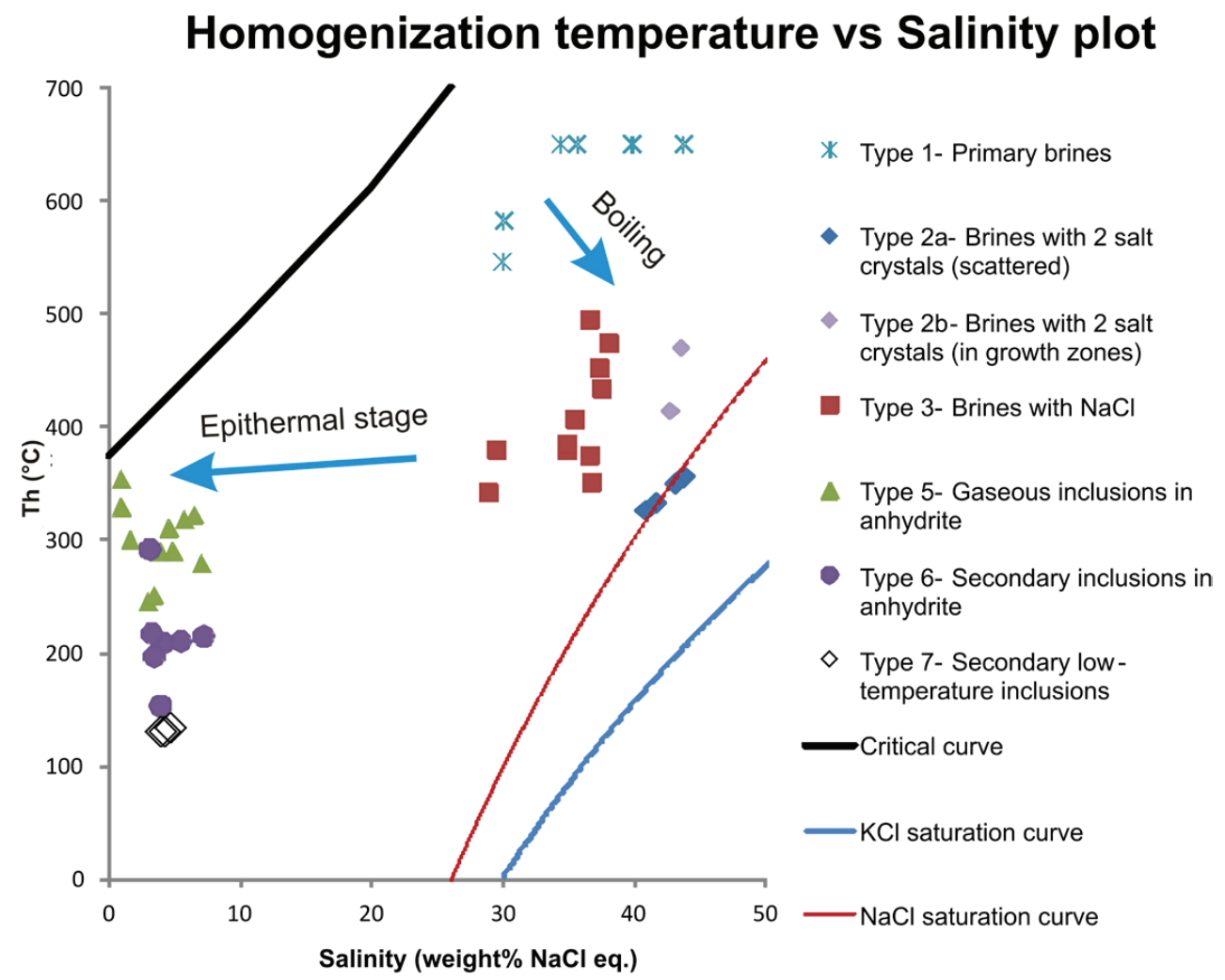

Figure 9. Plot of microthermometric measurements (salinity vs. homogenization temperature (Th) diagram) for different inclusions from Čukaru Peki. Data for the $\mathrm{H}_{2} \mathrm{O}$ critical curve and the $\mathrm{NaCl}$ saturation curve are given by HAAS (1976) and data for the $\mathrm{KCl}$ saturation curve is given by POTTER et al. (1978). Type 4 inclusions are not plotted on this diagram because there were no salinity (ice melting) measurements for these inclusions. Several type 1 inclusions didn't homogenize until $600^{\circ} \mathrm{C}$ (the limit of the used heating stage), so they are plotted around $650^{\circ} \mathrm{C}$.

stages of the evolution of porphyry systems, low-salinity fluids $\left(5-20 \% \mathrm{NaCl}\right.$ eq.) with temperatures between 250 and $350^{\circ} \mathrm{C}$ are introduced in the system from the parental magma chamber. The most representative sample for fluids in the transition zone is sample cp069 because it was sampled in the lower andesites high above the porphyry zone. Considering the facts that anhydrite veins commonly contain covellite and enargite and that gypsum is a common mineral in the high-sulphidation zone, it is possible that anhydrite inclusions in the transitional zone (types 5 and 6) trapped part of the fluids which deposited massive sulfides with covellite and enargite. However, previous fluid inclusion research on high-sulphidation mineralization in the Bor metallogenic zone (KOŽELJ, 2002; BAILLY et al., 2002) yielded somewhat lower temperatures (around $150-250^{\circ} \mathrm{C}$ ) than those inferred by our study of type 5 inclusions from Čukaru Peki. Another problem is that type 6 inclusions are usually related to later cracks in the analyzed veins, so their genetic link with any of the analysed veins or stages of mineralization is uncertain.

Sulphide veins in the transition zone are probably the remains of epithermal fluid flow paths to the high sulphidation zone since they contain larger amounts of pyrite, covellite and enargite. However, they do not contain transparent minerals, which makes them incompatible for standard fluid inclusion analysis using transmitted light microscopy.. Thus, further analyses of highsulphidation minerals (including infrared microthermometry) are needed for better constraining of fluid characteristics that led to deposition of massive sulfides.

Fluids trapped in inclusions type 6 and 7 are likely post-ore fluids, since their homogenization temperature is low and they are trapped in secondary inclusions in later cracks.

\section{CONCLUSIONS}

According to the presented petrographic observations of fluid inclusion assemblages from Čukaru Peki, together with the performed microthermotetrical measurements, it can be concluded that this hydrothermal system was formed in several different stages:

Analyzed quartz veins contain three types of primary inclusion assemblages:

1) Primary high-temperature assemblages (type 1) with homogenization temperatures above $550^{\circ} \mathrm{C}$ and high salinities.

2) Brine inclusion assemblages (type $2 \mathrm{a}$ ) with two or more solid phases (2 salt crystals \pm opaque crystal \pm hematite), scattered in quartz crystals.

3) The brine inclusion association containing 1) brine assemblages with salt crystals and opaque minerals (with occasional hematite) (type $2 \mathrm{~b}$ and type 3 ) and 2) apparently single-phase lowsalinity vapour-rich inclusions (type 4). Most of the inclusions in this association homogenize at around $400^{\circ} \mathrm{C}$. The coexistence and similar temperatures of homogenization of these three types of inclusions imply that these assemblages were trapped during the boiling of high-temperature fluids.

Considering the measured homogenization temperatures and estimated entrapment pressures of these coexisting inclusion assemblages, it is estimated that the boiling of fluids in this system occurred at temperatures between 350 and $450^{\circ} \mathrm{C}$ and pressures between 100 and 500 bars. The boiling of fluids was probably a very important factor in deposition of porphyry style mineralization in this system.

Analysed anhydrite veins contain two types of inclusion assemblages: 
1) Primary fluid inclusion assemblages (type 5) that sometimes contain opaque minerals and homogenize around $300^{\circ} \mathrm{C}$. Since these inclusions are primary in origin, it can be concluded that purple anhydrite and related ore minerals (which in some veins include covellite and enargite) were formed around $300^{\circ} \mathrm{C}$, with salinity of fluids between 0.87 and $7 \mathrm{wt} . \% \mathrm{NaCl}$ eq.

2) Secondary low-temperature fluid inclusion assemblages (inclusions type 6). Most of these inclusions were formed at temperatures lower than $200^{\circ}$ and they are probably not important for the mineralization.

The last generation of fluids that affected this system was trapped in secondary low-temperature inclusion assemblages (type 7). These fluids are trapped in secondary inclusion assemblages in quartz and anhydrite and their homogenization temperatures do not exceed $150^{\circ} \mathrm{C}$.

This research has provided data about the conditions of formation of veins from the porphyry and transitional zone of Čukaru Peki, however additional research is required to assess the physico-chemical conditions of fluids that led to the deposition of massive sulphides.

\section{ACKNOWLEDGMENT}

The authors would like to thank prof. Ronald BAKKER for his practical advice and help with determining different types of fluid inclusions from Čukaru Peki. The authors are also grateful to the sample preparation lab at the Department of Geology and Ore Deposits at Montanuniversitat Leoben in Austria for help with making double-polished sections for fluid inclusion analysis. This study is partly supported by the CEEPUS network and by the scientific project funded by the Serbian Ministry of Education, Science and Technological Development No 176016. V. CVETKOVIĆ is supported by the projects F17 and F9 of the Serbian Academy of Sciences and Arts.

\section{REFERENCES}

BAILLY, L., STEIN, G. \& GENNA, A. (2002): Preliminary microthermometric measurements in quartz, sphalerite and enargite from the Bor and Majdanpek deposits, Serbia.- In: Proceedings Geology and Metallogeny of Copper and Gold Deposits in the Bor Metallogenic Zone. Bor 100 Years International Symposium, Bor Lake, Yugoslavia, 2002, 71-75.

BAKKER, R J. (2012): Package FLUIDS. Part 4: Thermodynamic modelling and purely empirical equations for $\mathrm{H}_{2} \mathrm{O}-\mathrm{NaCl}-\mathrm{KCl}$ solutions. Mineralogy and petrology, 105/ (1-2), 1-29. doi: 10.1007/s00710-012-0192-z

BAKKER R.J. (2018): AqSo_NaCl: Computer program to calculate $\mathrm{p}-\mathrm{T}-\mathrm{X}-\mathrm{v}$ properties in the $\mathrm{H} 2 \mathrm{O}-\mathrm{NaCl}$ fluid system applied to fluid inclusion research and pore fluid circulation.-Comput. Geosci., 115, 122-133. doi: 10.1016/j.cageo.2018.03.003

BANJEŠEVIĆ, M. \& LARGE, D. (2014): Geology and mineralization of the new copper and gold discovery south of Bor Timok magmatic complex.-Proceedings of the XVI Serbian Geological Congress, Serbian Geological Society, Donji Milanovac, 2014, 739-741.

BANJEŠEVIĆ, M., CVETKOVIĆ, V., VON QUADT, A., LJUBOVIĆ OBRADOVIĆ, D., VASIĆ, N., PAČEVSKI, A. \& PEYTCHEVA, I. (2019). New Constraints on the Main Mineralization Event Inferred from the Latest Discoveries in the Bor Metallogenetic Zone (BMZ, East Serbia).-Minerals, 9/(11), 672. doi: 10.3390/min9110672

BODNAR, R.J. (1993): Revised equation and table for determining the freezing point depression of $\mathrm{H} 2 \mathrm{O}-\mathrm{NaCl}$ solutions.- Geochimica et Cosmochimica Acta, 57, 683-684. doi: 10.1016/0016-7037(93)90378-A

BODNAR, R.J. \& SAMSON, I. (2003): Reequilibration of fluid inclusions.- Fluid inclusions: Analysis and interpretation, 32, 213-230.

BODNAR, R.J., LECUMBERRI-SANCHEZ, P., MONCADA, D. \& STEELE-MACINNIS, M. (2014): 13.5 Fluid inclusions in hydrothermal ore deposits. Treatise on Geochemistry.- Second Editionth edn. Elsevier, Oxford, 119-142. doi: 10.1016/ b978-0-08-095975-7.01105-0

DRIESNER, T. \& HEINRICH, C.A. (2007): The system H2O-NaCl. Part I: Correlation formulae for phase relations in temperature-pressure-composition space from 0 to $1000 \mathrm{C}, 0$ to 5000 bar, and 0 to $1 \mathrm{XNaCl}$.- Geochimica et Cosmochimica Acta, 71/ (20), 4880-4901. doi: 10.1016/j.gca.2006.01.033
FOURNIER, R.O. (1999). Hydrothermal processes related to movement of fluid from plastic into brittle rock in the magmatic-epithermal environment.- Economic Geology, 94/(8), 1193-1211. doi: 10.2113/gsecongeo.94.8.1193

GALLHOFER, D., VON QUADT, A., PEYTCHEVA, I., SCHMID, S.M. \& HEINRICH, C.A. (2015): Tectonic, magmatic, and metallogenic evolution of the Late Cretaceous arc in the Carpathian-Balkan orogeny.- Tectonics, 34, 1813-1836. doi: $10.1002 / 2015$ TC003834

GOLDSTEIN, R.H. \& SAMSON, I. (2003) Petrographic analysis of fluid inclusions.Fluid inclusions: Analysis and interpretation, 32, 9-53.

HAAR, L. (1984): NBS/NRC steam tables.- CRC Press.

HAAS, J.L. (1976): Physical properties of the coexisting phases and thermochemical properties of the h2o component in boiling $\mathrm{NaCl}$ solutions.- US Geological Survey Bulletin, 1421-A, 1-71

HEINRICH, C.A. (2005): The physical and chemical evolution of low-salinity magmatic fluids at the porphyry to epithermal transition: a thermodynamic study.-Mineralium Deposita, 39/(8), 864-889. doi: 10.1007/s00126-004-0461-9

HEINRICH, C.A., HALTER, W., LANDTWING, M.R. \& PETTKE, T. (2005): The formation of economic porphyry copper (-gold) deposits: constraints from microanalysis of fluid and melt inclusions.- Geological Society, London, Special Publications, 248/(1), 247-263. doi: 10.1144/GSL.SP.2005.248.01.13

JANKOVIĆ, S. (1990): The ore deposits of Serbia: Regional metallogenic settings, environments of deposition, and types.- Faculty of Mining and Geology, Belgrade (in Serbian with English summary).

JELENKOVIĆ, R. (2014): A brief overview of the metallic mineral resources of Serbia-European Geologist, 37, 34-38.

JELENKOVIĆ, R., MILOVANOVIĆ, D., KOŽELJ, D. \& BANJEŠEVIĆ, M. (2016): The mineral resources of the Bor metallogenic zone: a review.- Geologia Croatica, 69/ (1), 143-155. doi: 10.4154/gc.2016.11

JOHN, D.A., AYUSO, R.A., BARTON, M.D., BLAKELY, R.J., BODNAR, R.J., DILLES, J.H. \& TAYLOR, R.D. (2010): Porphyry copper deposit model.- Scientific investigations report.

KOLB, M., VON QUADT, A., PEYTCHEVA, I., HEINRICH, C.A., FOWLER, S.J. \& CVETKOVIĆ, V. (2013): Adakite-like and normal arc magmas: distinct fractionation paths in the East Serbian segment of the Balkan-Carpathian arc.- Journal of Petrology, 54/(3), 421-451. doi: 10.1093/petrology/egs072

KOŽELJ, D.I. (2002): Epitermalna mineralizacija zlata borske metalogenetske zone: morfogenetski tipovi, strukturno-teksturni varijeteti i potencijalnost [Epithermal gold mineralization in the bor metallogenic zone: morphogenetic types, structural-texture varieties and potentiality - in Serbian, with English summary].- RTB Bor, Institut za bakar, Indok centar.

LECUMBERRI-SANCHEZ, P., STEELE-MACINNIS, M., \& BODNAR, R.J. (2012): A numerical model to estimate trapping conditions of fluid inclusions that homogenize by halite disappearance.- Geochimica et Cosmochimica Acta, 92, 14-22. doi: 10.1016/j.gca.2012.05.044

LECUMBERRI-SANCHEZ, P., STEELE-MACINNIS, M., WEIS, P., DRIESNER, T. \& BODNAR, R.J. (2015): Salt precipitation in magmatic-hydrothermal systems associated with upper crustal plutons.- Geology, 43/(12), 1063-1066. doi: 10.1130/ G37163.1

LI, S., ZHANG, X. \& GAO, L. (2019): Ore Genesis at the Jinchang Gold-Copper Deposit in Heilongjiang Province, Northeastern China: Evidence from Geology, Fluid Inclusions and H-O-S Isotopes.- Minerals, 9/(2), 99. doi: 10.3390/min9020099

MAO, W., RUSK, B., YANG, F. \& ZHANG, M. (2017): Physical and chemical evolution of the Dabaoshan porphyry Mo deposit, South China: Insights from fluid inclusions, cathodoluminescence, and trace elements in quartz.- Economic Geology, 112/(4), 889-918. doi: 10.2113/econgeo.112.4.889

MAVROGENES, J.A. \& BODNAR, R.J. (1994): Hydrogen movement into and out of fluid inclusions in quartz: experimental evidence and geologic implications.- Geochimica et Cosmochimica Acta, 58/(1), 141-148. doi: 10.1016/0016-7037(94)904529

NEUBAUER, F. (2002): Contrasting Late Cretaceous with Neogene ore provinces in the Alpine-Balkan-Carpathian-Dinaride collision belt.- Geological Society London Special Publication, 204, 90-100. doi: 10.1144/gsl.sp.2002.204.01.06

NI 43-101 (2016): Preliminary economic assessment of the Cukaru Peki upper zone deposit, Serbia, March 2016.

ORLANDEA, E. \& VLAD, S.-N. (2020): A novel conceptual model of intrusion related gold bearing systems and exploration tools.- Studia UBB Geologia 63/(1), 1-12. doi: $10.5038 / 1937-8602.63 .1 .1304$

POTTER, R.W., CLYNNE, M.A. \& BROWN, D.L. (1978): Freezing point depression of aqueous sodium chloride solutions.- Economic Geology, 73/(2), 284-285. doi: 10.2113/gsecongeo.73.2.284

REDMOND, P.B., EINAUDI, M.T., INAN, E.E., LANDTWING, M.R. \& HEINRICH, C.A. (2004): Copper deposition by fluid cooling in intrusion-centered systems: New insights from the Bingham porphyry ore deposit, Utah.- Geology, 32/(3), 217-220. doi: $10.1130 / \mathrm{G} 19986.1$ 
RICHARDS, J.P. (2005): Cumulative factors in the generation of giant calc-alkaline porphyry $\mathrm{Cu}$ deposits.- Super porphyry copper and gold deposits: A global perspective, 1, 7-25.

ROEDDER, E. (1984): Fluid inclusions.- De Gruyter, broj stranica.

RUSK, B.G., REED, M.H. \& DILLES, J.H. (2008): Fluid inclusion evidence for magmatic-hydrothermal fluid evolution in the porphyry copper-molybdenum deposit at Butte, Montana.-Economic Geology, 103/(2), 307-334. doi: 10.2113/gsecongeo.103.2.307

SILLITOE, R.H. (2010): Porphyry copper systems.- Economic geology, 105/(1), 3-41. doi: 10.2113/gsecongeo.105.1.3

STEELE-MACINNIS, M., LECUMBERRI-SANCHEZ, P. \& BODNAR, R.J. (2012): HOKIEFLINCS- $\mathrm{H}_{2} \mathrm{O}-\mathrm{NACL}$ : A Microsoft Excel spreadsheet for interpreting microthermometric data from fluid inclusions based on the PVTX properties of $\mathrm{H}_{2} \mathrm{O}-\mathrm{NaCl}$.- Computers Geosciences, 49, 334-337. doi: 10.1016/j.cageo.2012.01.022
STERNER, S.M., HALL, D.L. \& BODNAR, R.J. (1988): Synthetic fluid inclusions. V. Solubility relations in the system $\mathrm{NaCl}-\mathrm{KCl}-\mathrm{H} 20$ under vapor-saturated conditions.- Geochimica et Cosmochimica Acta, 52, 989-1005.

STRASHIMIROV, S. (1997): New data about the development of hydrothermal system in the Majdanpek porphyry copper deposit.- In Proceedings of Symposium "Ore deposit exploration", Belgrade 2-4.April 1997, 409-418.

VANKO, D.A. \& BACH, W. (2005): Heating and freezing experiments on aqueous fluid inclusions in anhydrite: Recognition and effects of stretching and the low-temperature formation of gypsum.- Chemical Geology, 223/(1-3), 35-45. doi: 10.1016/j.chemgeo.2004.11.021

VELOJIĆ M. \& ERLANDSSON, B.V.(2019): Trace elements in different veins by LAICP-MS in Chukaru Peki high sulfidation deposit, Serbia.- In: 1st International Student Conference on Geochemistry and Mineral Deposits, Prague.

WILKINSON, J.J. (2001): Fluid inclusions in hydrothermal ore deposits.- Lithos, 55/ (1-4), 229-272. doi: 10.1016/s0024-4937(00)00047-5 


\section{Appendix}

Table with all microthermometry measurements conducted on analyzed sam-ples from Čukaru Peki.

\begin{tabular}{|c|c|c|c|c|}
\hline Spot number & $\begin{array}{c}\text { Type of } \\
\text { inclusions }\end{array}$ & $\operatorname{Tm}\left({ }^{\circ} \mathrm{C}\right)$ & Phase & Th $\left({ }^{\circ} \mathrm{C}\right)$ \\
\hline $143-3$ & 1 & & & 580 \\
\hline $143-3$ & 1 & & & $>600$ \\
\hline $106-4$ & 1 & 268.8 & halite & $>600$ \\
\hline $106-4$ & 1 & 160 & halite & 582 \\
\hline $123-5$ & 1 & 157.5 & halite & 545 \\
\hline $105-3 b$ & 1 & 327 & halite & $>600$ \\
\hline $105-3 b$ & 1 & 328.2 & halite & $>600$ \\
\hline $105-2 b$ & 1 & 373 & halite & $>600$ \\
\hline $105-2 b$ & 1 & 248.7 & halite & $>600$ \\
\hline $96-2$ & $2 a$ & 356 & halite & 356 \\
\hline $106-1$ & $2 a$ & 350 & halite & 350 \\
\hline $116-6$ & $2 a$ & 326 & halite & 326 \\
\hline $106-1$ & $2 a$ & 350 & halite & 350 \\
\hline $105-3 b$ & $2 a$ & 333 & halite & 333 \\
\hline $105-2 a$ & $2 b$ & 353.9 & halite & 414 \\
\hline $105-2 a$ & $2 b$ & 364.1 & halite & 470 \\
\hline $96-2$ & 3 & 263 & halite & 407 \\
\hline $96-2$ & 3 & 278.7 & halite & 375 \\
\hline $96-2$ & 3 & 280 & halite & 495 \\
\hline $116-6$ & 3 & 300 & halite & 474 \\
\hline $116-8$ & 3 & 293 & halite & 434 \\
\hline $106-4$ & 3 & 290 & halite & 452 \\
\hline $89-4$ & 3 & 253 & halite & 379 \\
\hline $89-4$ & 3 & 281 & halite & 351 \\
\hline $89-3$ & 3 & 254.4 & halite & 384 \\
\hline $123-8$ & 3 & 146.8 & halite & 380 \\
\hline $105-3 a$ & 3 & 127.4 & halite & 342 \\
\hline $96-2$ & 4 & & & 403 \\
\hline $96-2$ & 4 & & & 387 \\
\hline $96-3$ & 4 & & & 331 \\
\hline $89-4$ & 4 & & & 371 \\
\hline $89-4$ & 4 & & & 390 \\
\hline $141-8$ & $4 a$ & & & 389 \\
\hline $141-9$ & $4 a$ & & & 428 \\
\hline $141-9$ & $4 a$ & & & 396 \\
\hline $89-3$ & 4 & & & 414 \\
\hline 89-3 & 4 & & & 377 \\
\hline 69-1 & 5 & -4.4 & ice & 279 \\
\hline $69-2$ & 5 & & & 297 \\
\hline $69-3$ & 5 & & & 298 \\
\hline $69-4$ & 5 & & & 249 \\
\hline $69-5$ & 5 & & & 283 \\
\hline $69-6$ & 5 & & & 299 \\
\hline $69-7$ & 5 & & & 316 \\
\hline $69-8$ & 5 & & & 299 \\
\hline 69-9 & 5 & & & 248 \\
\hline $69-10$ & 5 & & & 301 \\
\hline $69-11$ & 5 & & & 298 \\
\hline $69-12$ & 5 & & & 255 \\
\hline $69-13$ & 5 & & & 345 \\
\hline $69-14$ & 5 & & & 321 \\
\hline $69-15$ & 5 & & & 225 \\
\hline 69-16 & 5 & & & 258 \\
\hline
\end{tabular}

\begin{tabular}{|c|c|c|c|c|}
\hline Spot number & $\begin{array}{c}\text { Type of } \\
\text { inclusions }\end{array}$ & $\operatorname{Tm}\left({ }^{\circ} \mathrm{C}\right)$ & Phase & $\operatorname{Th}\left({ }^{\circ} \mathrm{C}\right)$ \\
\hline $69-17$ & 5 & & & 290 \\
\hline 69-18 & 5 & & & 334 \\
\hline 69-19 & 5 & & & 302 \\
\hline $69-20$ & 5 & & & 267 \\
\hline $110 a$ & 5 & -2.3 & ice & 289 \\
\hline $110 a$ & 5 & -3.5 & ice & 318 \\
\hline $110 a$ & 5 & -1.7 & ice & 245 \\
\hline $110 \mathrm{~g}-3$ & 5 & -2 & ice & 251 \\
\hline 110G-3 & 5 & -0.9 & ice & 300 \\
\hline $110-6$ & 5 & -2.9 & ice & 290 \\
\hline $110-7$ & 5 & -0.5 & ice & 329 \\
\hline $108-3 b$ & 5 & -4 & ice & 323 \\
\hline $108-3 b$ & 5 & & & 330 \\
\hline $108-3 b$ & 5 & & & 372 \\
\hline $108-3 b$ & 5 & & & 396 \\
\hline $108-4$ & 5 & -0.5 & ice & 353 \\
\hline $108-4$ & 5 & & & 294 \\
\hline $110 \mathrm{G}-3$ & 5 & & & 277 \\
\hline $110 \mathrm{G}-3$ & 5 & & & 286 \\
\hline $123-1$ & 5 & -2.7 & ice & 310 \\
\hline $123-1$ & 5 & & & 356 \\
\hline $110-7$ & 6 & -3.3 & ice & 211 \\
\hline $116-8$ & 6 & & & 237 \\
\hline $69-1$ & 6 & & & 220 \\
\hline $69-2$ & 6 & & & 204 \\
\hline $69-3$ & 6 & & & 179 \\
\hline $108-3 b$ & 6 & -2.4 & ice & 209 \\
\hline $108-5$ & 6 & -1.8 & ice & 292 \\
\hline $108-5$ & 6 & -1.9 & ice & 217 \\
\hline $110 \mathrm{~g}-1$ & 6 & & & 143 \\
\hline $110 g-4$ & 6 & & & 176 \\
\hline $110 \mathrm{~g}-4$ & 6 & & & 155 \\
\hline $110 \mathrm{~g}-4$ & 6 & & & 146 \\
\hline $123-1$ & 6 & -2 & ice & 197 \\
\hline $123-1$ & 6 & -2.3 & ice & 154 \\
\hline $123-1$ & 6 & -4.5 & ice & 215 \\
\hline $110 a$ & 6 & -2.3 & ice & 131 \\
\hline $89-3$ & 7 & & & 111 \\
\hline $89-3$ & 7 & & & 115 \\
\hline $89-3$ & 7 & & & 117 \\
\hline $89-3$ & 7 & & & 118 \\
\hline $89-3$ & 7 & & & 120 \\
\hline $89-3$ & 7 & & & 142 \\
\hline $141-7$ & 7 & & & 73 \\
\hline $141-7$ & 7 & & & 87 \\
\hline $108-3 a$ & 7 & & & 91 \\
\hline $108-3 a$ & 7 & & & 89 \\
\hline $108-3 a$ & 7 & -2.5 & ice & 131 \\
\hline $108-3 b$ & 7 & & & 76 \\
\hline $108-5$ & 7 & -2.8 & ice & 134 \\
\hline $108-5$ & 7 & & & 139 \\
\hline $105-3 b$ & 7 & & & 69 \\
\hline $105-3 b$ & 7 & & & 161 \\
\hline
\end{tabular}

